\title{
ANALISIS KUALITAS PELAYANAN DALAM FASILITAS KESEHATAN TINGKAT PERTAMA OLEH IBU HAMIL PESERTA JAMINAN KESEHATAN NASIONAL DI DUA KLINIK KECAMATAN DENPASAR SELATAN
}

\author{
Ni Luh Hitakirana Dewi, Ni Luh Gde Ari Natalia Yudha, Made Agus Sugianto \\ Program Studi Kesehatan Masyarakat, Universitas Dhyana Pura \\ Email : arinataliayudha@udhirabali.ac.id
}

\begin{abstract}
ABSTRAK
Pengukuran keberhasilan suatu jasa dalam memberikan pelayanan adalah melalui kualitas pelayanan yang diberikan. Kualitas pelayanan akan terpenuhi apabila proses penyampaian jasa dari pemberi jasa kepada pasien sesuai dengan apa yang dipersepsikan oleh pasien, terdapat lima dimensi kualitas pelayanan yang perlu diperhatikan yaitu; Tangibles (Penampilan fisik), Reliability (Keandalan), Responsiveness (Daya tanggap), Assurance (Jaminan) dan Empathy (Empati). Tujuan umum dari penelitian ini adalah untuk mengetahui gambaran dari lima dimensi kualitas pelayanan pada Klinik X dan Klinik Y dan untuk mengetahui perbandingan antara kedua Klinik tersebut. Metode penelitian: kuantitatif yang bersifat komparatif dengan metode pendekatan yang dilakukan adalah Cross sectional. Jumlah sampel yaitu 84 responden Ibu Hamil dengan teknik pengambilan accidental sampling dan menggunakan kuisioner sebagai instrumen penelitian. Uji analisis data yang digunakan adalah Kolmogorov Smirnov. Hasil penelitian ini setelah dilakukan uji analisa didapatkan hasil nilai Signifikan $=0,036$ karena nilai Signifikan $<0,05$ menyatakan adanya perbedaan antara Klinik X dan Klinik Y.
\end{abstract}

Kata Kunci: Kualitas Pelayanan, Ibu Hamil, Klinik

\begin{abstract}
Of the ways to measure the success of service provider is through the quality of services provided. Service quality will be fulfilled if the service delivery process from the service provider to the patient is in accordance with the patient's perception, there are five dimensions of service quality that need to be considered namely; Tangibles, Reliability, Responsiveness, Assurance and Empathy. The general objective of this study is to describe the five dimensions of service quality at the Clinic $X$ and the Clinic $Y$ and to find a comparison between the two clinics. Research method: quantitative comparative with the Cross sectional approach method. The number of samples is 84 respondents of pregnant women with accidental sampling techniques and using questionnaires as research instruments. The analysis test used was Kolmogorov Smirnov. The results of this study after the analysis test obtained the results of the Sig. $=0.036$ because the value of Sig $<0,05$ denote a difference between Clinic $X$ and Clinic $Y$.
\end{abstract}

Keyword: Service Quality, Pregnant Women, Clinics

\section{PENDAHULUAN}

Menurut Survey Demografi dan Kesehatan Indonesia (SDKI), angka kematian ibu (AKI) yaitu 359 per 100.000 kelahiran hidup pada tahun 2012. Terjadi peningkatan dari tahun 2007 yaitu sebesar 228 per 100.000 kelahiran hidup (SDKI, 2012). Sedangkan AKI di provinsi Bali pada tahun 2006 sampai dengan 2015 sudah mencapai target MDGs yaitu kurang dari 102 per 100.000 kelahiran hidup, di kota Denpasar angka kematian ibu sebesar 56 per 100.000 kelahiran hidup. Namun demikian, trendnya sangat fluktuatif yakni masih mengalami naik turun sehingga diharapkan target AKI di Provinsi Bali dapat menurun setiap tahunnya (Dinas Kesehatan Provinsi Bali, 2015). Untuk mewujudkan hal tersebut diselenggarakan pelaksanaan Jaminan Kesehatan Nasional (JKN) bagi kesehatan perorangan. JKN yang dikembangkan di Indonesia merupakan bagian dari Sistem Jaminan Sosial Nasional (SJSN).

Pada tahun 2004, pemerintah mengeluarkan Undang-Undang No.40 tentang Sistem Jaminan Sosial Nasional (SJSN) yang mengamanatkan bahwa jaminan sosial wajib bagi seluruh penduduk termasuk JKN melalui badan penyelenggara yaitu Badan Penyelenggara Jaminan Sosial (BPJS). Selain itu Undang-Undang No.24 tahun 2011 menetapkan JKN akan diselenggaran oleh BPJS, yang terdiri oleh BPJS Kesehatan dan BPJS Ketenagakerjaan (Kemenkes RI, 2013).

Pelayanan Kesehatan bagi peserta JKN terdiri dari Pelayanan Kesehatan Tingkat Pertama dan Pelayanan Kesehatan Rujukan atau Tingkat Lanjutan. Pada Permenkes RI No.71 tahun 2013 tentang pelayanan kesehatan dan jaminan kesehatan nasional, fasilitas pelayanan kesehatan tingkat 
pertama dapat berupa Puskesmas atau yang setara yaitu, praktik dokter, praktik dokter gigi (Kemenkes RI, 2013).Terdapat delapan Fasilitas Kesehatan Tingkat Pertama (FKTP) yang ada di Kecamatan Denpasar Selatan. Kunjungan ibu Hamil yang terbanyak ada pada Klinik X dan Klinik Y. Data yang diperoleh dari Faskes Tingkat Pertama (FKTP) di Klinik Y menggambarkan bahwa kunjungan ibu hamil mengalami peningkatan yaitu pada tahun 2016 kunjungan ibu hamil yaitu sebanyak 276 kunjungan, tahun 2017 sebanyak 303 kunjungan dan tahun 2018 sebanyak 348 kunjungan. Di Klinik X juga mengalami peningkatan kunjungan dari tahun 2016 yaitu sebanyak 88 kunjungan, tahun 2017 sebanyak 183 kunjungan, dan tahun 2018 sebanyak 243 kunjungan. Namun terdapat perbedaan yang signifikan dari kedua klinik tersebut yang menunjukkan bahwa kunjungan pasien di Klinik Y memiliki kunjungan yang lebih banyak dibandingkan dengan Klinik X. Hasil pengumpulan data awal menunjukkan bahwa kedua Klinik memiliki karakteristik yang sama seperti SDM, peralatan, kepadatan penduduk yang sama di Kecamatan Denpasar Selatan yaitu kepadatan penduduk yaitu 5330 per $\mathrm{km}^{2}$ (BPS, 2010).

Terdapat berbagai faktor yang memengaruhi pengguna JKN untuk memilih FKTP. Menurut Halwi (2016), faktor jarak lokasi pelayanan dan faktor sosial ekonomi (pendidikan, pekerjaan, pendapatan) ikut memengaruhi dalam pemilihan FKTP. Faktor kepuasan pasien atas pelayanan kesehatan, faktor kualitas pelayanan kesehatan yang diberikan dan faktor hubungan kedekatan dengan tenaga kesehatan yang memberikan pelayanan juga ikut memmengaruhi pengambilan keputusan pemilihan FKTP.

Menurut penelitian ( Gunawan and S. Pantja Djati 2011), pengukuran keberhasilan suatu jasa dalam memberikan pelayanan adalah melalui kualitas pelayanan yang diberikan. Persepsi pasien tentang pelayanan memegang peran yang sangat penting. Salah satunya ditentukan oleh Kualitas pelayanan yang diberikan, dimana kualitas pelayanan akan terpenuhi apabila proses penyampaian jasa dari pemberi jasa kepada pasien sesuai dengan apa yang dipersepsikan oleh pasien, terdapat lima dimensi kualitas pelayanan yang perlu diperhatikan yaitu; Reliability (Keandalan), Responsiveness (Daya tanggap), Assurance (Jaminan), Empathy (Empati), Tangibles (Penampilan fisik).

Sesuai dengan penelitian sebelumnya maka peneliti ingin mengetahui ada atau tidaknya pengaruh kualitas pelayanan dalam pemilihan FKTP dengan tujuan penelitian Untuk mengetahui gambaran dari lima dimensi kualitas pelayanan pada Klinik $\mathrm{X}$ dan Klinik $\mathrm{Y}$ dan untuk mengetahui perbandingan antara kedua FKTP tersebut.

\section{METODE PENELITIAN}

Penelitian ini merupakan penelitian kuantitatif yang bersifat komparatif, dengan metode pendekatan yang dilakukan adalah cross sectional. Penelitian dilakukan pada bulan April 2019 di Klinik X dan Klinik Y. Populasi penelitian ini adalah ibu hamil pada Klinik X dan Klinik Y dengan pengambilan jumlah sampel menggunakan rumus Slovin (Sugiyono, 2010) dan didapatkan sampel 84 orang dengan kriteria inklusi yaitu ibu hamil yang melakukan kunjungan pada saat penelitian dan ibu hamil yang bersedia menjadi responden dan kriteria eksklusi ibu hamil yang bukan pasien dari Klinik serta ibu hamil yang tidak bersedia menjadi responden pada saat wawancara awal di pengambilan data.

\section{HASIL PENELITIAN}

Berdasarkan tabel di atas, persentase usia didominasi oleh usia 21-30 tahun sebanyak 28 orang $(33,33 \%)$ dari Klinik X dan 29 orang $(34,52 \%)$ dari Klinik Y. Berdasarkan pendidikan, persentase pendidikan didominasi oleh pendidikan SMA sebanyak 17 orang $(20,23 \%)$ dari Klinik X dan 17 orang $(20,23 \%)$ dari Klinik Y.

Tabel 1. Karakteristik Responden pada Klinik X dan Klinik Y

\begin{tabular}{lllcccc}
\hline \multirow{2}{*}{ No } & \multirow{2}{*}{ Karakteristik Responden } & \multicolumn{2}{c}{ Klinik X } & \multicolumn{2}{c}{ Klinik Y } \\
& & $\begin{array}{c}n=84 \\
\text { Responden }\end{array}$ & Persentase & $n=84$ & Persentase \\
Responden & \\
\hline 1 & Pendidikan & SMP & 3 & $3,57 \%$ & 4 & $4,76 \%$ \\
& & SMA & 17 & $20,23 \%$ & 17 & $20,23 \%$ \\
& & DIPLOMA & 8 & $9,52 \%$ & 8 & $9,52 \%$ \\
\multirow{4}{*}{2} & \multirow{2}{*}{ Usia } & S1 & 14 & $16,67 \%$ & 13 & $15,48 \%$ \\
& & S20 Tahun & 3 & $3,57 \%$ & 1 & $1,19 \%$ \\
& & $21-30$ Tahun & 28 & $33,33 \%$ & 29 & $34,52 \%$ \\
& & $31-40$ Tahun & 11 & $13,10 \%$ & 12 & $14,29 \%$ \\
\hline
\end{tabular}


Tabel 2. Analisis Deskriptif pada Dimensi Pernyataan Tangible

\begin{tabular}{lcccl}
\hline \multirow{1}{*}{\multicolumn{1}{c}{ Pernyataan }} & \multicolumn{2}{c}{ Klinik X } & \multicolumn{2}{c}{ Klinik Y } \\
& $\begin{array}{c}\text { Total Rata- } \\
\text { Rata Skor }\end{array}$ & Kategori & $\begin{array}{c}\text { Total Rata- } \\
\text { Rata Skor }\end{array}$ & Kategori \\
\hline Kondisi Fisik Klinik & 3,31 & Sedang & 3,36 & Sedang \\
Penampilan Petugas Klinik & 3,31 & Sedang & 3,33 & Sedang \\
Peralatan yang dimiliki Klinik & 3,31 & Sedang & 3,38 & Sedang \\
Sarana dan Prasarana Pendukung & 3,31 & Sedang & 3,40 & Baik \\
\multicolumn{1}{c}{ Total Rata-Rata } & 3,31 & Sedang & 3,37 & Sedang \\
\hline
\end{tabular}

Tabel 3. Analisis Deskriptif pada Dimensi Pernyataan Reliability

\begin{tabular}{lcccc}
\hline \multicolumn{1}{c}{ Pernyataan } & \multicolumn{2}{c}{ Klinik X } & \multicolumn{2}{c}{ Klinik Y } \\
& $\begin{array}{c}\text { Total Rata- } \\
\text { Rata Skor }\end{array}$ & Kategori & $\begin{array}{c}\text { Total Rata- } \\
\text { Rata Skor }\end{array}$ & Kategori \\
& 3,50 & Baik & 3,40 & Baik \\
\hline $\begin{array}{l}\text { Kecepatan pelayanan } \\
\text { kesehatan }\end{array}$ & 3,29 & Sedang & 3,29 & Sedang \\
$\begin{array}{l}\text { Ketepatan menerbitkan surat } \\
\text { rujukan }\end{array}$ & 3,21 & Sedang & 3,36 & Sedang \\
$\begin{array}{l}\text { Kemampuan pengoperasian } \\
\text { peralatan kesehatan }\end{array}$ & 3,34 & Sedang & 3,35 & Sedang \\
\hline \multicolumn{1}{c}{ Total Rata-Rata } & & & & \\
\hline
\end{tabular}

Pada pernyataan Tangible (Penampilan Fisik) terlihat bahwa rata-rata skor jawaban responden dari kedua klinik tersebut termasuk dalam kategori sedang, dengan Klinik Y yang memiliki total ratarata skor yang lebih tinggi yaitu 3,37 dengan nilai skor paling tinggi pada pernyataan nomor empat yaitu tentang sarana dan prasarana pendukung yang dimiliki oleh Klinik.

Pada pernyataan Reliability (Keandalan) terlihat bahwa rata-rata skor jawaban responden dari kedua klinik tersebut termasuk dalam kategori sedang, dengan Klinik Y yang memiliki total ratarata skor yang lebih tinggi yaitu 3,35. Pada kedua klinik tersebut pernyataan nomor lima yaitu tentang kecepatan petugas kesehatan dalam memberikan pelayanan memiliki skor jawaban yang sama-sama tinggi. Namun pada Klinik $\mathrm{X}$ pada pernyataan nomor tujuh yaitu tentang kemampuan operasiona peralatan memiliki skor paling rendah diantara kedua klinik tersebut.

Pada pernyataan Responsiveness (Daya Tanggap) terlihat bahwa rata-rata skor jawaban responden dari Klinik $\mathrm{X}$ termasuk dalam kategori sedang yaitu 3,25 sedangkan Klinik Y termasuk dalam kategori baik yaitu 3,42 dengan nilai skor paling tinggi pada pernyataan nomor sepuluh yaitu tentang petugas mengerti dan memahami keinginan pasien.

Tabel 4. Analisis Deskriptif pada Dimensi Pernyataan Responsiveness

\begin{tabular}{|c|c|c|c|c|}
\hline \multirow[b]{2}{*}{ Pernyataan } & \multicolumn{2}{|c|}{ Klinik X } & \multicolumn{2}{|c|}{ Klinik Y } \\
\hline & $\begin{array}{l}\text { Total Rata- } \\
\text { Rata Skor }\end{array}$ & Kategori & $\begin{array}{l}\text { Total Rata- } \\
\text { Rata Skor }\end{array}$ & Kategori \\
\hline Sikap pelayanan petugas kesehatan & 3,40 & Baik & 3,38 & Sedang \\
\hline Perhatian petugas kesehatan & 3,24 & Sedang & 3,43 & Baik \\
\hline $\begin{array}{l}\text { Mengerti dan memahami } \\
\text { keinginan pasien }\end{array}$ & 3,12 & Sedang & 3,45 & Baik \\
\hline $\begin{array}{l}\text { Petugas mendengarkan keluhan } \\
\text { pasien }\end{array}$ & 3,24 & Sedang & 3,40 & Baik \\
\hline Total Rata-Rata & 3,25 & Sedang & 3,42 & Baik \\
\hline
\end{tabular}


Tabel 5. Analisis Deskriptif pada Dimensi Pernyataan Assurance

\begin{tabular}{lcccc}
\hline \multirow{1}{*}{ Pernyataan } & \multicolumn{2}{c}{ Klinik X } & \multicolumn{2}{c}{ Klinik Y } \\
& $\begin{array}{c}\text { Total Rata- } \\
\text { Rata Skor }\end{array}$ & Kategori & $\begin{array}{c}\text { Total Rata- } \\
\text { Rata Skor }\end{array}$ & Kategori \\
\hline $\begin{array}{l}\text { Perasaan Ibu saat dilakukan } \\
\text { pemeriksaan }\end{array}$ & 3,33 & Sedang & 3,29 & Sedang \\
Sikap petugas unit pengaduan & 3,26 & Sedang & 3,38 & Sedang \\
$\begin{array}{l}\text { Persetujuan tindakan } \\
\text { Kepastian jaminan }\end{array}$ & 3,21 & Sedang & 3,38 & Sedang \\
$\quad$ Total Rata-Rata & 3,29 & Sedang & 3,36 & Sedang \\
& 3,27 & Sedang & 3,35 & Sedang \\
\hline
\end{tabular}

Tabel 6. Analisis Deskriptif pada Dimensi Pernyataan Empathy

\begin{tabular}{|c|c|c|c|c|}
\hline \multirow[b]{2}{*}{ Pernyataan } & \multicolumn{2}{|c|}{ Klinik X } & \multicolumn{2}{|c|}{ Klinik Y } \\
\hline & $\begin{array}{l}\text { Total Rata- } \\
\text { Rata Skor }\end{array}$ & Kategori & $\begin{array}{l}\text { Total Rata- } \\
\text { Rata Skor }\end{array}$ & Kategori \\
\hline Keramahan dan kesopanan petugas & 3,36 & Sedang & 3,50 & Baik \\
\hline $\begin{array}{l}\text { Kesabaran petugas melayani } \\
\text { pasien }\end{array}$ & 3,31 & Sedang & 3,45 & Baik \\
\hline $\begin{array}{l}\text { Kemampuan petugas melayani } \\
\text { keluhan pasien }\end{array}$ & 3,36 & Sedang & 3,45 & Baik \\
\hline Kepedulian petugas kepada pasien & 3,29 & Sedang & 3,45 & Baik \\
\hline Total Rata-Rata & 3,33 & Sedang & 3,46 & Baik \\
\hline
\end{tabular}

Tabel 7. Analisis Deskriptif Pengkategorian Skor pada Kualitas Pelayanan Klinik X dan Klinik Y

\begin{tabular}{cccccc}
\hline No & Pengkategorian & \multicolumn{2}{c}{ Klinik X } & \multicolumn{2}{c}{ Klinik Y } \\
& Skor & F & $\%$ & F & $\%$ \\
\hline 1 & Baik & 17 & 20,2 & 30 & 35,7 \\
2 & Cukup & 25 & 29,8 & 12 & 14,3 \\
\hline
\end{tabular}

Pada pernyataan Assurance (Jaminan) terlihat bahwa rata-rata skor jawaban responden dari kedua klinik tersebut termasuk dalam kategori sedang, dengan Klinik Y yang memiliki total rata-rata skor yang lebih tinggi yaitu 3,35 dengan nilai skor paling tinggi pada pernyataan nomor 13 yaitu tentang sikap petugas unit pengaduan jika ibu mengadu karena pelayanan tidak baik dan nomor 14 yaitu tentang persetujuan tindakan oleh petugas kesehatan ketika akan melakukan pemeriksaan.

Pada pernyataan Empathy (Empati) terlihat bahwa rata-rata skor jawaban responden dari Klinik $\mathrm{X}$ termasuk dalam kategori sedang yaitu 3,33 sedangkan Klinik Y termasuk dalam kategori baik yaitu 3,46 dengan nilai skor paling tinggi pada pernyataan nomor 16 yaitu tentang keramahan dan kesopanan petugas melayani pasien.

Berdasarkan hasil analisis dari Tabel 5 diperoleh hasil dari 42 responden pada Klinik Y diperoleh hasil yaitu hampir setengah responden atau 30 responden $(35,7 \%)$ menyatakan kualitas pelayanan di Klinik Y adalah baik sedangkan pada Klinik X diperoleh hasil yaitu hampir setengah responden atau 25 responden $(29,8 \%)$ menyatakan kualitas pelayanan di Klinik X adalah cukup.

Hasil statistik Kolmogorov-Smirnov $=1,418$ dengan nilai Sig. $=0,036$. Nilai Sig. $=0,036<0,05$ sehingga dapat disimpulkan Ho ditolak dan $\mathrm{Ha}$ diterima. Berdasarkan hasil tersebut dapat disimpulkan bahwa ada perbedaan dari kedua klinik tersebut.

\section{PEMBAHASAN \\ Dimensi Tangible}

Pada dimensi Tangible (Penampilan Fisik) kedua Klinik termasuk dalam kategori sedang, terlihat bahwa skor paling tinggi didapatkan oleh Klinik Y pada pernyataan nomor empat yaitu tentang sarana dan prasarana pendukung yang dimiliki oleh Klinik dan skor paling rendah didapatkan oleh Klinik X yaitu pada pernyataan 
nomor satu sampai dengan nomor empat yang dimana berarti menurut pernyataan responden sarana dan prasarana yang dimiliki oleh Klinik Y lebih baik dibandingkan dengan Klinik X.

Hasil penelitian ini juga didukung oleh penelitian sebelumnya dengan judul Kualitas Layanan dan Loyalitas Pasien di kota Singaraja, Bali yang menyatakan bahwa Tangible (Penampilan Fisik) mempunyai pengaruh positif dan signifikan terhadap tingkat loyalitas pasien.

\section{Dimensi Reliability}

Pada dimensi Reliability (Kehandalan) kedua Klinik termasuk dalam kategori sedang terlihat bahwa pada kedua klinik tersebut pernyataan nomor lima yaitu tentang kecepatan petugas kesehatan dalam memberikan pelayanan memiliki skor jawaban yang sama-sama tinggi. Namun pada Klinik X pada pernyataan nomor tujuh yaitu tentang kemampuan operasional peralatan memiliki skor paling rendah diantara kedua klinik tersebut.

Hasil penelitian ini juga didukung oleh oleh penelitian sebelumnya dari Ketut Gunawan and S. Pantja Djati (2011) dengan judul Kualitas Layanan dan Loyalitas Pasien di kota Singaraja, Bali yang menyatakan bahwa Reliability (Kehandalan) mempunyai pengaruh positif dan signifikan terhadap tingkat loyalitas pasien dimana pasien memerlukan layanan yang serba cepat dalam segala segi bentuk pelayanan. Dengan demikian, dapat dikatakan bahwa efektivitas waktu pelayanan akan menentukan loyalitas pasien dalam jangka panjang.

\section{Dimensi Responsiveness}

Pada dimensi Responsiveness (Daya tanggap), terlihat bahwa Klinik Y termasuk dalam kategori baik dengan skor rata-rata yaitu 3,42 dimana nilai skor paling tinggi didapatkan pada pernyataan nomor sepuluh yaitu tentang petugas mengerti dan memahami keinginan pasien sedangkan Klinik X termasuk dalam kategori sedang dengan skor paling rendah yaitu juga pada pernyataan nomor sepuluh.

Hasil penelitian ini juga didukung oleh oleh penelitian sebelumnya dari (Gunawan and Pantja Djati 2011) dengan judul Kualitas Layanan dan Loyalitas Pasien di kota Singaraja, Bali yang menyatakan bahwa Responsiveness (Daya tanggap) mempunyai pengaruh positif dan signifikan terhadap tingkat loyalitas pasien yang dimana ketanggapan petugas atas keluhan dan masalah yang dihadapi mempengaruhi pasien dalam memberikan tanggapan yang positif terhadap dimensi Responsiveness (Daya tanggap).

\section{Dimensi Assurance}

Pada dimensi Assurance (Jaminan) kedua Klinik termasuk dalam kategori sedang terlihat bahwa Klinik Y memiliki skor paling tinggi pada pernyataan nomor 13 yaitu tentang sikap petugas unit pengaduan jika ibu mengadu karena pelayanan tidak baik dan nomor 14 yaitu tentang persetujuan tindakan oleh petugas kesehatan ketika akan melakukan pemeriksaan sedangkan pada Klinik X memiliki skor paling rendah pada pernyataan nomor 14 yang dimana menyatakan masih kurangnya pelaksanaan dalam melakukan persetujuan tindakan sebelum melakukan pemeriksaan.

Hasil penelitian ini juga didukung oleh penelitian sebelumnya dari Ketut Gunawan and S. Pantja Djati (2011) yang menyimpulkan bahwa variabel Assurance (Jaminan) mempunyai hubungan dan pengaruh yang signifikan dengan variabel loyalitas dimana fasilitas kesehatan harus mampu memberikan jaminan kepada pasien dalam bentuk kemampuan dan pengetahuan, jaminan keamanan, jaminan keselamatan, perilaku petugas yang baik dan pengalaman yang memadai.

\section{Dimensi Empathy}

Pada dimensi Empathy (Empati) Klinik Y termasuk dalam kategori baik dengan nilai skor paling tinggi pada pernyataan nomor 16 yaitu tentang keramahan dan kesopanan petugas melayani pasien sedangkan pada Klinik $\mathrm{X}$ termasuk dalam kategori sedang dengan skor paling rendah didapatkan pada pernyataan nomor 19 yaitu tentang kepedulian petugas terhadap pasien yang masih kurang.

Hasil penelitian ini juga didukung oleh penelitian sebelumnya dari (Gunawan and Pantja Djati 2011) yang menyimpulkan terdapat hubungan yang searah antara dimensi empati (emphaty) terhadap loyalitas pasien yang dimana petugas kesehatan harus mampu dalam memberikan perhatian penuh kepada pasien yang berkaitan rasa pengertian, pemahaman petugas dan kepedulian yang tinggi dari petugas.

\section{Perbandingan antara Kedua Klinik}

Dari tabel pengkategorian skor dari ke-lima variabel kualitas pelayanan pada kedua klinik didapatkan hasil bahwa Pada Klinik X bahwa hampir setengah responden atau 25 responden $(29,8 \%)$ menyatakan kualitas pelayanan di Klinik X adalah cukup sedangkan pada Klinik Y didapatkah hasil bahwa hampir setengah responden atau 30 responden $(35,7 \%)$ menyatakan kualitas pelayanan di Klinik Y adalah baik. Berdasarkan hasil uji statistik Kolmogorov-Smirnov hasil nilai Sig. = 0,036. Sig. $=0,036<0,05$ yang menyatakan bahwa berdasarkan analisa data didapatkan hasil adanya perbedaan kualitas pelayanan di kedua klinik tersebut. 
Hasil penelitian ini didukung oleh penelitian dari (Gunawan and Pantja Djati, 2011) yang menyatakan pengukuran keberhasilan suatu jasa dalam memberikan pelayanan adalah melalui kualitas pelayanan yang diberikan. Persepsi pasien tentang pelayanan memegang peran yang sangat penting. Salah satunya ditentukan oleh Kualitas pelayanan yang diberikan, dimana kualitas pelayanan akan terpenuhi apabila proses penyampaian jasa dari pemberi jasa kepada pasien sesuai dengan apa yang dipersepsikan oleh pasien.

Menurut analisis peneliti, perbedaan yang terjadi antara kualitas pelayanan dari kedua klinik tersebut disebabkan oleh lima variabel kualitas pelayanan di masing-masing klinik yang berbeda yang dimana menurut responden Klinik Y memiliki kualitas pelayanan yang lebih baik.

\section{KESIMPULAN}

a. Dari 42 responden di masing-masing Klinik pada dimensi Tangible (Penampilan Fisik) didapatkan hasil nilai total rata-rata skor pada Klinik Y adalah 3,37 yang termasuk dalam kategori sedang dan nilai total rata-rata skor pada Klinik X adalah 3,31 yang termasuk dalam kategori sedang yang dimana pada Klinik $X$ dan Klinik Y pada fasilitas, sarana dan prasarana masih belum dalam kategori Baik.

b. Dari 42 responden di masing-masing Klinik pada dimensi Reliability (Kehandalan) didapatkan hasil nilai total rata-rata skor pada Klinik $\mathrm{Y}$ adalah 3,35 yang termasuk dalam kategori sedang dan nilai total rata-rata skor pada Klinik X adalah 3,34 yang termasuk dalam kategori sedang yang dimana pada Klinik X dan Klinik Y kecepatan dan ketepatan petugas kesehatan dalam memberikan pelayanan, serta peningkatan kemampuan operasional pada peralatan masih belum dalam kategori Baik.

c. Dari 42 responden di masing-masing Klinik pada dimensi Responsiveness (Daya Tanggap) didapatkan hasil nilai total rata-rata skor pada Klinik Y adalah 3,42 yang termasuk dalam kategori baik dan nilai total rata-rata skor pada Klinik $X$ adalah 3,25 yang termasuk dalam kategori sedang yang dimana pada klinik $X$ sikap petugas dalam memberikan pelayanan masih belum termasuk dalam kategori Baik.

d. Dari 42 responden di masing-masing Klinik pada dimensi Assurance (Jaminan) didapatkan hasil nilai total rata-rata skor pada Klinik Y adalah 3,35 yang termasuk dalam kategori sedang dan nilai total rata-rata skor pada Klinik $\mathrm{X}$ adalah 3,27 yang termasuk dalam kategori sedang yang dimana klik X dan Klinik Y pada kepastian jaminan yang diberikan masih belum dalam kategori Baik.

e. Dari 42 responden di masing-masing Klinik pada dimensi Empathy (Empati) didapatkan hasil nilai total rata-rata skor pada Klinik Y adalah 3,40 yang termasuk dalam kategori baik dan nilai total rata-rata skor pada Klinik $\mathrm{X}$ adalah 3,33 yang termasuk dalam kategori sedang yang dimana pada klinik X kepedulian petugas dalam memberikan pelayanan masih belum dalam kategori Baik.

f. Dari 42 responden diperoleh hasil yaitu hampir setengah responden atau 30 responden $(35,7 \%)$ menyatakan kualitas pelayanan di Klinik Y adalah baik dan pada Klinik X diperoleh hasil yaitu hampir setengah responden atau 25 responden $(29,8 \%)$ menyatakan kualitas pelayanan cukup.

g. Hasil nilai Sig. $=0,036$. Sig. $=0,036<0,05$ sehingga dapat disimpulkan Ho ditolak dan $\mathrm{Ha}$ diterima yang berarti menyatakan adanya perbedaan antara Klinik X dan Klinik Y

\section{SARAN}

Berdasarkan hasil penelitian diatas maka saran yang dapat disampaikan adalah sebagai berikut:

a. Klinik X dan Klinik Y perlu meningkatkan kondisi fisik dari Klinik jika diperlukan renovasi, penampilan dari para petugas kesehatan, peralatan yang dipergunakan serta sarana dan prasarana yang dapat lebih ditingkatkan.

b. Klinik X dan Klinik Y perlu meningkatkan kecepatan dan ketepatan petugas kesehatan dalam memberikan pelayanan, serta peningkatan kemampuan operasional pada peralatan yang digunakan agar pemeriksaan lebih maksimal dapat dilakukan.

c. Klinik X perlu meningkatkan sikap petugas dalam memberikan pelayanan, petugas diharapkan dapat mampu memberikan perhatian, serta lebih mengerti dan memahami keinginan dari pasien dan keluhan dari pasien.

d. Klinik $\mathrm{X}$ dan Klinik $\mathrm{Y}$ perlu meningkatkan jaminan keamanan yang diberikan dari Klinik pada setiap pemeriksaan agar pasien merasa aman dan nyaman dalam melakukan pemeriksaan.

e. Klinik X perlu meningkatkan keramahan, kesopanan, kesabaran dan kepedulian serta bagaimana petugas mampu menyelesaikan keluhan pasien yang perlu ditingkatkan.

\section{DAFTAR PUSTAKA}

Arikunto (2010) Prosedur Penelitian: Suatu Pendekatan Praktik (Edisi Revisi), Jakarta: 
Rineka Cipta. doi: 10.1017/CBO9781107415324.004.

BPJS Kesehatan (2016) 'Ini Strategi Kepatuhan dan Pemantapan Layanan BPJS Kesehatan 2016', Info BPJS Kesehatan, (33), p. 12.

Cronin, J., K., Michael G. Brady \& Thomas M. Hult.2000. "Assesing The Effects of Quality, Value, and Customer Satisfaction on Consumer Behavioral Intentions in Service Environment", Journal of Retailing, page 193-218.

Dinas Kesehatan Provinsi Bali (2015) 'Profil Kesehatan Provinsi Bali Tahun 2015', Profil Kesehatan Provinsi Bali, p. 142. Available at: http://www.diskes.baliprov.go.id/files/subdoma in/diskes/Profil Kesehatan Provinsi Bali/Tahun 2015/Bali_Profil_2015.pdf.

Halwi, S. (2016) 'Preferensi Pemanfaatan Fasilitas Kesehatan Tingkat Pertama (FKTP) Oleh Peserta BPJS Mandiri Di Kecamatan Banda Sakti Kota Lhokseumawe Tahun 2016'.

Haryono, Erwin, Hari Kusnanto \& M. Syafril Nusyirwa. 2006. Hubungan Persepsi terhadap Kualitas Pelayanan dengan Minat Pemanfaatan Pelayanan Rawat Inap Puskesmas dan Balai Pengobatan Swasta di Kabupaten Tapanuli Tengah, Working Paper Series No.4, Universitas Gadjah Mada

Janis, N. (2014) 'BPJS Kesehatan, Supply dan Demand terhadap Layanan Kesehatan', Kemenkeu, pp. 1-8.

Kemenkes RI (2013) 'Buku Pegangan Sosialisasi Jaminan Kesehatan Nasional dalam Sistem Jaminan Sosial Nasional', Departemen Kesehatan RI, pp. 1-75. doi: 10.1017/CBO9781107415324.004.

Ketut Gunawan and S. Pantja Djati (2011) 'Kualitas Layanan dan Loyalitas Pasien (Studi pada Rumah Sakit Umum Swasta di Kota SingarajaBali)', Jurnal Manajemen dan Kewirausahaan, 13(1), pp. 32-39. doi: 10.9744/jmk.13.1.32-39.
Kotler (2013) Manajemen Pemasaran Jilid 2, Penerbit Erlangga. doi: 10.1074/jbc.M303084200.

Muninjaya, A. A. Gde., 2011. (2011) 'MUNIJAYA 2011 Manajemen Mutu Pelayanan Kesehatan. Jakarta: EGC.', in Manajemen Mutu Pelayanan Kesehatan. Jakarta: EGC.

Notoatmodjo, S. (2012) Promosi Kesehatan dan Perilaku Kesehatan, Jakarta: Rineka Cipta. doi: 10.1038/cmi.2015.110.

Nursalam (2008) Konsep Dan Teori Metodologi Penelitian Ilmu Keperawatan, Salemba Medika. doi: 10.1007/0-387-36274-6_24.

Parasuraman, A. (2002) Service quality and productivity: A synergistic perspective', Managing Service Quality: An International Journal, 12(1), pp. 6-9. doi: 10.1108/096045202104.

Sabihaini. 2002. "Analisis Konsekuensi Keperilakuan Kualitas Layanan: Suatu Kajian Empirik ,Usahawan, hal: 29-36.

Survey Demografi dan Kesehatan Indonesia (SDKI). $2012 . \quad$ Angka Kematian Ibu. Dikutip dari www.bkkbn.co.id diakses pada tanggal 13 Maret 2016

Sugiyono (2010) 'Populasi dan sampel', Populasi dan sampel, 5(1976), pp. 265-288. doi: 10.1093/nar/gkp846.

Tjiptono, F. and Tjiptono, F. (2012) 'Service management: mewujudkan layanan prima / Fandy Tjiptono', ,Service management: mewujudkan layanan prima / Fandy Tjiptono, 2012(2012), pp. 1-99. doi: 10.1519/JPT.0b013e31826e7d33.

WHO/UNICEF (2015) '2015 Update and MDG Assessment', World Health Organization, p. 90. doi: 10.1007/s13398-014-0173-7.2. 